УДК 316:774

DOI:

Олеся Власій, докторант Прикарпатського начіонального університету імені Василя Стефаника

\title{
ФОРМУВАННЯ ОСОБИСТОСТІ ШКОЛЯРА В ЦИФРОВУ ЕПОХУ: МОЖЛИВОСТІ ТА ВИКЛИКИ
}

Стаття присвячена проблемі формування особистості школяра за умов розвитку цифрових технологій. Авторка проаналізувала останні дослідження та публікачії з проблеми формування особистості за умов иифровізиії освіти, а також документи Європейського Союзу, резолюиії Генеральної Асамблеї ООН тощьо. Цифрові технології пропонують нові можливості для доповнення, збагачення і трансформачії освіти. Інформачійно-комунікаційні технології є ключовим інструментом для сприяння рівного й всеохопного доступу до освіти, подолання розривів у навчанні, відкриття нових перспектив для вчителів та їхньої професії, підвищення якості та змісту навчання, а також удосконалення системи управління освітою. Схарактризовано виклики і ризики, перед якими опинилася сьогодні класична освіта. Зроблено висновок, щзо виклики ичифровоі епохи значною мірою спричиняють переосмислення форм, засобів та методів навчання. Інертність класичноі освіти спричинила появу нових форм освіти - неформальної та інформальної. Розглянуто можливі ризики розвитку особистості в різних контекстах ичифрових трансформацій.

Ключові слова: цифрова епоха; особистість школяра; цифрова освіта; інформаційно-комунікачійні технології; ичиррові технології.

Jim. 16.

Olesya Vlasiy, Doctoral Student, Vasyl Stefanyk Precarpathian National University

\section{FORMING THE STUDENT'S PERSONALITY IN THE DIGITAL ERA: OPPORTUNITIES AND CHALLENGES}

The article is devoted to the problem of forming the student's personality under the conditions of digital technologies progress. The digitalization of education requires a lot of effort to master the new technologies by both students and teachers. Students face particularly acute challenges, because during the transformation of education, there are no established norms and rules of conduct in the new educational space. The author analyzed the latest research and publications on the problem of personality formation in the context of digitalization of education, as well as documents of the European Union, UN General Assembly resolutions, etc. Digital technologies offer new opportunities to complement, enrich and transform of education. Information and communication technologies are a key tool for promoting the equal and inclusive access to education, bridging learning gaps, opening new perspectives for teachers and their professions, improving the quality and content of education, and improving the education management system. The challenges and risks faced by classical education today are analyzed. It is concluded that the challenges of the digital era significantly lead to a rethinking of forms, tools and methods of teaching. The inertia of classical education has led to the emergence of new forms of education - non-formal and informal. Possible risks of personality development in different contexts of digital transformations are considered. The diversity of educational opportunities can, in turn, be seen again as a challenge to open space, because the large number of available educational resources does not mean their quality. And in order to choose quality educational resources, critical thinking is needed. An analysis of threats and challenges that arise in the open information and educational space reveals the importance of skills needed by individuals in the XXI century: critical and creative thinking, cooperation and communication, information and technology literacy, flexibility, initiative, productivity, socialization.

Keywords: digital era; the student's personality; digital education; an information and communication technologies; digital technologies.

П остановки проблеми. У зв'язку зі стрімким розвитком цифрових технологій виникає потреба в переосмисленні діяльності та взаємодії людей у всіх, без винятку, сферах діяльності. Зокрема, постає проблема трансформації освітніх систем, які повинні сприяти розвитку навичок та компетентностей, необхідних особистості у XXI ст. і які б відповідали потребам суспільства в цифрову епоху. Цифровізація освіти вимагає багато зусиль для освоєння нових технологій як учнями, так і вчителями. Водночас стрімке настання цифрової епохи зумовлює появу низки загроз і небезпек для сучасної людини, адже технології розвиваються швидше, аніж освітня система може адаптуватися до них. Особливо гостро такі виклики стоять перед школярами, адже в період трансформації освіти немає усталених норм та правил поведінки в новому освітньому просторі. 
Аналіз останніх досліджень та публікацій. Начебто недавно, якщо дивитися у розрізі цивілізаційного розвитку, 2001 р. М. Пренський увів поняття цифрових аборигенів й проаналізував умови, в яких ростуть і розвиваються діти, народжені в епоху цифрових технологій. Ще тоді було наголошено на цифровому розриві між поколіннями - цифровими аборигенами (які ростуть змалку з комп'ютерами, гаджетами та інтернетом) і цифровими іммігрантами (які тільки починають освоювати нові для них технології), а також на необхідності переосмислення підходів до навчання й виховання [5]. Праця Марка Пренського викликала багато дискусій в освітній сфері, однак поставлена проблема була очевидною. 2015 р. в праці “Цифрові аборигени: хто вони?" автори наголошують як на потребі формування новітніх навичок дитини, так і на ризику втрати навичок, набутих поколіннями [1]. Історичний аналіз розвитку ідеї класу цифрових аборигенів та дискусій навколо нього протягом 1998-2017 pp. докладно аналізує Т. Джадд [3], роблячи висновок про те, що цифрові технології $\epsilon$ ключовою частиною особистого та соціального життя учнів, відіграють центральну роль у навчанні і ці тенденції неможливо не враховувати в освітній діяльності.

Проблема діяльності людини та функціонування суспільства в нових умовах гостро постала перед суспільством на планетарному рівні. У резолюції, ухваленій Генеральною Асамблеєю ООН 25 вересня 2015 р., визначається Порядок денний у сфері сталого розвитку до 2030 р., у якому, зокрема, зазначено, що “поширення інформаційнокомунікаційних технологій та глобальна взаємопов'язаність, як і науково-технічні інновації у таких різних галузях, як медицина і енергетика, мають величезний потенціал для прискорення прогресу людства, усунення “цифрового розриву” та розвитку суспільства, грунтованого на знаннях" [13]. Серед цілей сталого розвитку до 2030 p. однією 3 провідних визначено забезпечення всеохопної і справедливої якісної освіти та заохочення можливості навчання впродовж усього життя для всіх. У листопаді 2019 р. Парламентська асамблея Ради Європи ухвалила резолюцію "Роль освіти в цифрову еру: від “цифрових аборигенів” до “цифрових громадян”, у якій наголошується на ролі та цінності освіти в сучасному суспільстві, що все більше оцифровується. За таких умов повинні зазнати істотного стратегічного переосмислення такі поняття, як викладання та навчання, освітній простір, партнерство та оцінювання. У Резолюції наголошено, що сучасна освіта повинна відповідати не лише за формування у “цифрових аборигенів" навичок та компетентностей відповідно до потреб ринку праці, що швидко зростають але і допомогти ї стати відповідальними цифровими громадянами.

Мета дослідження - проаналізувати можливості та виклики формування особистості школяра в цифрову епоху.

Виклад основного матеріалу. Цифрові технології пропонують нові можливості для доповнення, збагачення і трансформації освіти. Інформаційно-комунікаційні технології (IКТ) є ключовим інструментом для сприяння рівному й всеохопному доступу до освіти, подолання розривів у навчанні, відкриття нових перспектив для вчителів та їхньої професії, підвищення якості та змісту навчання, а також удосконалення системи управління освітою.

Однак, за даними СС, майже 44 \% дорослих у країнах-членах Свропейського Союзу мають не достатні цифрові навички, а 20 \% - не мають їх узагалі, менше половини дітей навчаються у школах, обладнаних сучасною технікою, і лише від 20-25 \% учителів впевнено використовують технології у класі. За методологією оцінки цифрових навичок, яка застосовується Європеиською комісією, було оцінено рівень цифрових навичок українців. За даними Міністерства цифрової трансформації, 37,9 \% украінців у віці 18-70 р. мають цифрові навички на рівні нижче середнього, а ще 15,1 \% взагалі не володіють ними, 53 \% населення Украіни перебувають нижче позначки “середніи рівень". У листопаді 2020 р. Міністерство цифрової трансформації України запустило “Цифрограм”національний тест на цифрову грамотність, метою якого є оцінка загального рівня цифрової грамотності українців та виявлення прогалини в цифрових навичках.

“Цифрові аборигени”, хоча і добре володіють неформальним використанням високотехнологічних інструментів та соціальних медіа, не обов'язково вчаться систематично використовувати ІКТ в академічних умовах. На сьогоднішній день, за даними $Є С$, від 50 \% до 80 \% школярів ніколи не користувалися цифровими підручниками, програмним забезпеченням чи навчальними іграми. Набуття цифрових навичок починається ще в школі, де відбувається формування цифрової компетентності школярів, але, зі свого боку, необхідно, щоб заклади освіти та педагоги мали усі необхідні засоби для цього. Однією $з$ цілей проєкту Європейського освітнього простору СС $\epsilon$ забезпечення того, щоб до 2025 р. всі школи в Європейському Союзі мали доступ до 
широкосмугових мереж, і це 3 адекватною фінансовою підтримкою. Інші держави-члени Ради Європи не користуються подібними ресурсами та структурами підтримки. Парламентська асамблея стурбована тим, що такі істотні диспропорції можуть створити нові соціальні розбіжності як усередині європейських країн, так і між ними.

Чимало країн за межами Європейського Союзу вклали значні інвестиції в оснащення шкіл IКТ. Однак Асамблея нагадує, що технологічні інвестиції, здійснені без повної інтеграції ІКТ у процеси викладання та навчання, не призведуть до бажаних змін в освіті. Необхідна велика зміна парадигми, щоб перефокусувати освіту з передачі знань на створення знань та з освітнього процесу вчителя на процес навчання студента. Ця зміна парадигми повинна супроводжуватися правильно визначеними стратегічними цілями; посиленою автономією шкіл та вчителів; упровадженням нових гібридних форм навчання там, де зливаються мобільні, цифрові, віртуальні, соціальні i фізичні навчальні простори; істотним реформуванням в оцінюванні учнів.

У цьому процесі молоді люди мають бути забезпечені відповідними навичками та компетентностями, щоб стати ефективними й відповідальними дійовими особами у світі, який усе більше оцифровується [2], [10]. Асамблея вітає установи Європейського Союзу за їхню роботу в цій галузі, зокрема за ухвалення Плану дій Свропейської Комісії у галузі цифрової освіти у 2018 р. та за розроблення всеохопних основ цифрової компетентності для громадян і освітян.

Процес набуття цифрових навичок потрібно починати з раннього віку, а тривати він повинен протягом усього життя. Вивчення робототехніки, кодування, кібербезпеки, блокчейну та штучного інтелекту становитиме основу майбутніх схем освіти і навчання. Активне, проблемне навчання, яке охоплює різні предметні галузі, буде корисним для творчості й інновацій. Асамблея наголошує на актуальності встановлення мінімального рівня цифрових компетентностей, які повинні здобути студенти під час навчання, та критеріїв їх оцінки. У зв'язку з цим Асамблея вітає Настанови Ради Європи щодо поваги, захисту та реалізації прав дитини в цифровому середовищі, які надають вичерпні вказівки в цій галузі, зокрема щодо сприяння та розвитку цифрової грамотності. Також актуалізується питання цифрової комптентності жінок: хоча молоді жінки та молоді чоловіки почуваються достатньо кваліфікованими для використання цифрових технологій у своєму повсякденному житті, усе ще існує значний гендерний розрив у питанні представництва молодих жінок у сфері IKT.

На форумі в Гаазі було представлено звіт ООН "Епоха цифрової взаємозалежності", створення якого ініціював Генеральний Секретар ООН з метою оцінки впливів цифрових технологій на різні сфери діяльності суспільства, щоб максимізувати позитивні та мінімізувати негативні впливи цифрових технологій [6]. Частиною звіту стала Декларація цифрової взаємозалежності, яка визначає цілі на 2030 рік для країн-членів ООН у застосуванні технологій на благо суспільства. 3поміж ключових положень Декларації - питання доступності інтернету для користувачів, що не вичерпується тільки доступом, а й передбачає забезпечення відповідної інфраструктури технологій, дотримання прав людини за умов цифрової взаємодії з визначенням норм та меж застосування технологій для захисту приватності користувачів та їх безпеки, зокрема впровадження нагляду та стандартів щодо використання штучного інтелекту.

Донедавна вчитель і школа мали монополію на поширення знань. Це було до революційного розвитку соціальних мереж та інформаційних технологій. Світ навколо змінюється швидше i глибше, аніж будь-коли. За таких умов неможливо уникнути переоцінки загальних цінностей, а також самобутності та ролі класичних інституцій, серед яких - заклад освіти, який від початкової школи до університету з покоління до покоління задавав напрям розвитку суспільству.

Вплив глобалізаційних процесів, зумовив появу нового поняття "освітній простір", визначення якого викликало багато дискусій та трансформацій [11], [12], [16]. Водночас із цим терміном нерозривно пов'язане поняття відкритої освіти як складника реформування освітнього процесу, можливості якої аналізує автор аналітичної записки [8]. Цікавим прикладом елемента відкритої освіти є “живий” онлайндокумент “Open Education Handbook”, у якому аналізується сутність відкритої освіти, відображаються передові дослідження та інновації в цій галузі, демонструється синергія різних аспектів відкритої освіти, зокрема таких, як відкриті ресурси, відкриті дані, відкриті практики та відкрита культура [4]. Цей посібник складено провідними експертами галузі на допомогу освітнім спільнотам для кращого розуміння значення відкритої освіти.

Значною мірою появу відкритої освіти спричинила швидкість поширення інтернетмережі, що зумовило стрімкий розвиток нових освітніх технологій та забезпечило доступність 
до інформаційних та навчальних ресурсів здобувачів освіти. В таких умовах з'явилося безліч нових можливостей для усіх учасників освітнього процесу, але одночасно - і безліч загроз. I якщо глобалізація та відкритість освітнього простору відкриває нові можливості для вмотивованих та професійно-зорієнтованих здобувачів освіти, то окремої особливої уваги заслуговує факт формування особистості школяра, який потребує підтримки та скерування на шляху до професійного самовизначення і який має надто багато спокус видимої легкості досягнення освітнього результату. Системні освітні проблеми та ризики для розвитку особистості у відкритому освітньому просторі інформаційного суспільства досить докладно проаналізовано в [11], однак проблема ризиків та пошуку шляхів їх подолання у процесі формування особистості школяра в час становлення цифрового суспільства потребує більш ретельного вивчення.

Доступність технологій та інформації часто спричиняє першу реакцію - “заборонити”. Однак заборона - це або ж тимчасово, або навіть контрпродуктивно. Справді, можна заборонити, до прикладу, використання інтернету на уроці, проте ми розуміємо, що сучасна особистість не живе у замкнутому просторі, а інтернет-технології доступні на кожному кроці, тому така заборона здебільшого спричинить пошук інших можливостей отримання інформації. 3 іншого боку, використання інтернету відкриває доступ до ресурсів, які важко систематизувати, не маючи розуміння та критичного осмислення їх вмісту. За таких умов необхідно трансформувати методики навчання, беручи до уваги реалії, у яких перебуває сучасний школяр. А така трансформація неможлива без глибинного розуміння ризиків та можливостей, які спричиняє активне впровадження інформаційно-комунікаційних технологій в освітній процес, які детально проаналізували науковці В. Биков, О. Спірін, О. Пінчук [7].

У праці “Невідворотне” К. Келлі акцентує на дванадцяти технологіях, що формують майбутнє цифрового суспільства, і напрямах їхнього застосування, та слушно зазначає, що “технології - це каталізатор людства” [9]. Саме в контексті розглянутих змін, які очікуються у цифровому суспільстві, і проаналізуємо ризики та можливості для розвитку особистості школяра. Як наголошує К. Келлі, кращими за протистояння радикальним технологіям $є$ пильність та відкритість. Перефразуємо такий підхід в освітньому контексті: краще навчити, як це працює і як цим правильно користуватися, аніж заборонити. Розглянемо докладніше можливі ризики розвитку особистості в різних контекстах цифрових трансформацій.

Прискорення темпів змін цифрового середовища спричиняє постійну потребу в навчанні, оновленні професійних навичок та розвитку професійних вмінь. Доступність технологій - це добре, але це видима омана зручності, оскільки їх підтримка потребує розуміння базових принципів їх функціонування. У зв'язку зі швидкими цифровими змінами необхідне постійне переосмислення цього розуміння, що неможливе без неперервного навчання. Таким чином, ми доходимо цікавого висновку, який, 3 практичного досвіду, стає дивовижним відкриттям для учнів: що швидше вдосконалюються цифрові технології, то швидше потрібно вчитися, що складніші і "розумніші" стають технології, то розумніші повинні ставати їх користувачі, не кажучи вже про творців. А отже, відкритість - це не легкість отримання інформації, а можливість для саморозвитку та самовдосконалення.

Розвиток итучного інтелекту прискорили три важливі досягнення в IT-сфері: паралельне обчислення, великі масиви даних, удосконалення алгоритмів. Чи можливими були б ці винаходи, якщо б освітній процес спинився на доступності до вже досягнутого - питання риторичне. Зручність чи панування суперкомп'ютерів над людиною? Таке просте питання вже не стосується розділу наукової фантастики, а постає перед сучасною людиною як виклик. Як потрібно розвиватися людині, щоб бути господарем цифрового простору, а не його рабом? Саморозвиток та самовдосконалення, причому в напрямі розвитку творчих здібностей та критичного мислення. У конкуренції з роботами на виконання однакових завдань людина програє. Значить, вона повинна вчитися робити те, чого не вмітимуть вони. Такий простий приклад краще змушує задуматися над новим призначенням людини в суспільстві.

Потоковість як третя ера обчислень спричиняє перехід у режим реального часу. Сучасне покоління звикає до миттєвих реакцій на свої запити, а розв'язання задач, які вимагають тривалішого часу, стає проблематичнішим. Отже, постає проблема кліпового мислення [15]. Однак усе, що можна отримати миттєво, так само можуть отримати інші. Усе, що можна скопіювати, так само можуть скопіювати інші. Проблема плагіату, яка по-новому зазвучала у відкритому інформаційно-освітньому просторі, спричинена доступністю потокової інформації. За таких умов 
гостро постає питання розвитку творчих здібностей, адже в епоху потоковості, доступності та хмарності незрівнянно зросте цінність тих речей, які неможливо скопіювати, тобто цінність творчості.

Взаємодія та комунікація - це одні з підвалин функціонування сучасного суспільства. Рівень комунікації дає змогу функціонувати успішним фірмам, які не мають офісів, а працівники яких живуть в різних частинах земної кулі. Розвиток технологій спричиняє необхідність розв'язання здебільшого комплексних завдань, розв'язання яких без взаємодії практично неможливе. Навички роботи в команді стають одними 3 найбільш запротребуваних на ринку праці. У такому випадку надзвичайно важливим $\epsilon$ розвиток у школярів відповідних навичок. Приклад бірюзових організацій у такому контексті уможливить задуматися над відповідальністю та обов'язками кожного виконавця комплексного завдання.

3бір даних - усеосяжний інтернет створений для того, щоб збирати дані. Збір даних спричиняє доступність, що дуже зручно і чим легко користується кожен. Але практика опитування показує, що над питанням збору інформації “про себе особисто" задумуються не так часто. Зручності, які пропонують цифрові технології, здебільшого базуються на обробці даних, зібраних про користувачів. Про небезпеки в інтернеті говоримо дуже часто, але варто задуматися знову ж таки над простим запитанням: що про мене відомо іншим? Відповідь проста і для багатьох несподівана - інші про вас знають практично все, що хоч раз з'явилося в мережі, навіть у приватному листуванні Відкритість простору для особистості - це зручність, але відкритість особистості для простору змушує задуматися. I що швидше - то краще. Адже це повинно привести до переосмислення себе як частини відкритого простору і загроз, які в цьому приховані, причому неявно.

Перелічені виклики цифрової епохи (і це ще далеко не всі) значною мірою спричиняють переосмислення форм, засобів та методів навчання. Інертність класичної освіти привела до появи нових форм освіти - неформальної та інформальної [14]. Різноманіття можливостей здобуття освіти можна, своєю чергою, знову розглядати як виклик відкритого простору, адже велика кількість доступних освітніх ресурсів не означає їх якість. А для того, щоб обрати якісні освітні ресурси, необхідне критичне мислення.

Висновки та перспективи подальших досліджень. Настання цифрової епохи спричинило низку важливих перетворень у всіх сферах життєдіяльності людини, що зумовило необхідність трансформації системи освіти, однак така трансформація ускладнюється стрімким розвитком цифрових технологій, що випереджає попит на навички та компетентності сучасної людини порівняно з пропозицією освітнього ринку. Сучасний школяр опиняється в умовах невизначеності освітніх підходів і стандартів. Аналіз загроз та викликів, які виникають у відкритому інформаційно-освітньому просторі, розкриває важливість навичок, які необхідні особистості у XXI ст.: критичне і творче мислення, співпраця й комунікація, інформаційна та технологічна грамотність, гнучкість, ініціативність, продуктивність, соціалізація. Перспективним напрямом подальших досліджень може стати аналіз шляхів використання цифрових технологій для розвитку саме цих навичок.

\section{ЛIТЕРАТУРА}

1. Dingli A., Seychell D. Who Are the Digital Natives? The New Digital Natives. Springer, Berlin, Heidelberg. 2015. URL: https://doi.org/10.1007/978-3-662-46590-5 2

2. Ghamrawi N. A. R. Schooling for Digital Citizens. Open Journal of Leadership. 2018, 7, pp. 209-224. https:/ /doi.org/10.4236/oj1.2018.73012

3. Judd T. The rise and fall (?) of the digital natives. Australasian Journal of Educational Technology. 2018.

34(5). URL:https://doi.org/10.14742/ajet.3821

4. Open Education Handbook. 2017. URL: https://bit.ly/ 2UCbdJV

5. Prensky, M. Digital Natives, Digital Immigrants Part 1. On the Horizon. 2001. 9(5). pp. 1-6.

6. The Age of Digital Interdependence. The High-level Panel on Digital Cooperation. URL: https://www.un.org/ en/pdfs/DigitalCooperation-report-for $\% 20$ web.pdf

7. Биков В., Спірін О., Пінчук, О. Сучасні завдання цифрової трансформації освіти. Вісник Кафедри ЮНЕСКО "Неперервна професійна освіта XXI століття". 2020.(1).С. 27-36. https://doi.org/10.35387/ ucj.1(1).2020.27-36

8. Іщенко А. Відкрита освіта: новітні технології у навчальному процесі та освітньому менеджменті як засіб інтенсифікації розвитку освітньо-наукової системи України: аналітична записка. Національний інститут стратегічних досліджень: офіційне Інтернет-представниитво. URL: http://old2. niss.gov.ua/articles/721

9. Кевін Келлі Невідворотне. 12 тенологій, що формують наше майбутнє / Пер. 3 англ. Наталія Валевська. Київ, 2018.314 с.

10. Красновська I. П. Теоретичне обгрунтування понять “компетенція" “ “компетентність” у дослідженнях науковців (друга половина XX - початок XXI століття). Педагогічний альманах. 2020. (45). С. 233-238. https:// doi.org/10.37915/pa.vi45.76

11. Петренко Н.В. Освітній простір інформаційного суспільства як простір ризику для розвитку людини. Грані. 2016. №5(133). С. 35-40. doi:10.15421/171606 
12. Разуменко О. Освітній простір як місце розгортання педагогічних відносин. Вісник ХНПУ імені Г. С. Сковороди. Філософія. Том 2. №41. URL: http:// journals.hnpu.edu.ua/index.php/philosophy/article/view/ $\underline{2249}$

13. Резолюція "Перетворення нашого світу: Порядок денний у сфері сталого розвитку до 2030 року”. URL: http://sdg.org.ua/ua/resources-2/344-2030-2015

14. Савош В. О. Засобово орієнтовані складники системи неперервної освіти: різноаспектний аналіз формальної, інформальної та неформальної освіти. Педагогічний альманах. 2020. (45). С. 35-41. https:// doi.org/10.37915/pa.vi45.64

15. Соболєва С.М. Кліпове мислення як соціальнопсихологічний феномен та його роль у навчальнопізнавальній діяльності студентів. Теорія і практика сучасної психологіï. 2019. https://doi.org/10.32840/26636026.2019.3-2.16

16. Цимбалару А.Д. Освітній простір: сутність, структура і механізми створення. Український педагогічний журнал. 2016. № 1. C. 41-50. URL: https:/ /bit.ly/3phP8hD

\section{REFERENCES}

1. Dingli, A.\& Seychell, D. (2015). Who Are the Digital Natives? In: The New Digital Natives. Springer, Berlin, Heidelberg. https://doi.org/10.1007/978-3-662-46590-5 2 [in English].

2. Ghamrawi, N. A. R. (2018). Schooling for Digital Citizens. Open Journal of Leadership, 7, pp.209-224. https:/ /doi.org/10.4236/ojl.2018.73012 [in English].

3. Judd, T. (2018). The rise and fall (?) of the digital natives. Australasian Journal of Educational Technology, 34(5). https://doi.org/10.14742/ajet.3821 [in English].

4. Open Education Handbook (2017). Available at: https://bit.ly/2UCbdJV [in English].

5. Prensky, M. (2001). Digital Natives, Digital Immigrants Part 1. On the Horizon, 9(5), pp.1-6. [in English]

6. The Age of Digital Interdependence. The High-level Panel on Digital Cooperation. Available at: https:// www.un.org/en/pdfs/DigitalCooperation-reportfor\%20web.pdf [in English].

7. Bykov, V., Spirin, O., \& Pinchuk, O. (2020). Suchasni zavdannia tsyfrovoi transformatsii osvity [Modern tasks of digital transformation of education]. UNESCO Chair Journal "Lifelong Professional Education in the XXI Century”, (1), pp.27-36. https://doi.org/10.35387/ ucj.1(1).2020.27-36 [in Ukrainian].

8. Ischenko, I. Vidkryta osvita: novitni tekhnolohii u navchalnomu protsesi ta osvitnomu menedzhmenti yak zasib intensyfikatsii rozvytku osvitno-naukovoi systemy Ukrainy: analitychna zapyska [Open education: the new technologies in the educational process and educational management as a means of intensifying the development of the educational and scientific system of Ukraine: an analytical note]. The National Institute for Strategic Studies. Available at: http://old2.niss.gov.ua/articles/721 [in Ukrainian].

9. Kevin, Kelly (2018). Nevidvorotne. 12 tenolohii, shcho formuiut nashe maibutnie [Technological Forces That Will Shape The Future]. Translation from English Nataliia Valevska. Kyiv. [in Ukrainian].

10. Krasnovska, I. (2020). Teoretychne obhruntuvannia poniat "kompetentsiia" i "kompetentnist" u doslidzhenniakh naukovtsiv (druha polovyna XX pochatok XXI stolittia) [Theoretical justification of "competence" and "competency" terms in research of scientists (second half of XX - beginning of XXI centuries)]. Pedagogical Almanac, (45), pp.233-238. https://doi.org/10.37915/pa.vi45.76 [in Ukrainian].

11. Petrenko, N.V. (2016). Osvitnii prostir informatsiinoho suspilstva yak prostir ryzyku dlia rozvytku liudyny. [Educational space of information society as a space of risk for human development]. Grani. No.5(133), pp.35-40. doi:10.15421/171606 [in Ukrainian].

12. Razumenko, O. Osvitnii prostir yak mistse rozghortannia pedahohichnykh vidnosyn [Educational environment as the deployment of pedagogical relations]. Announcer of H. S. Skovoroda Kharkiv National Pedagogical University. Philosophy. 2. No.41. Available at: http://journals.hnpu.edu.ua/index.php/philosophy/ article/view/2249 [in Ukrainian].

13. Rezoliutsiia "Peretvorennia nashoho svitu: Poriadok dennyi u sferi staloho rozvytku do 2030 roku". [Resolution "Transforming our world: The 2030 Agenda for Sustainable Development"]. (2015). Available at: http:/ /sdg.org.ua/ua/resources-2/344-2030-2015 [in Ukrainian].

14. Savosh, V. O. (2020). Zasobovo oriientovani skladnyky systemy neperervnoi osvity: riznoaspektnyi analiz formalnoi, informalnoi ta neformalnoi osvity [Tooloriented components of continuous education system: different analysis of formal, informal and non-formal education]. Pedagogical Almanac. (45), pp.35-41. https:/ /doi.org/10.37915/pa.vi45.64 [in Ukrainian].

15. Sobolieva, S. M. (2019). Klipove myslennia yak sotsialno-psykholohichnyi fenomen ta yoho rol u navchalno-piznavalnii diialnosti studentiv [Clip thinking as a socio-psychological phenomenon and its role in the educational and cognitive activity of students]. Theory and practice of modern psychology. https://doi.org/ 10.32840/2663-6026.2019.3-2.16 [in Ukrainian].

16. Tsymbalaru, A. D. (2016). Osvitnii prostir: sutnist, struktura i mekhanizmy stvorennia [Educational space: essence, structure and mechanisms of creation]. Ukrainian pedagogical journal. V.1. 41-50. Available at: https://bit.ly/3phP8hD [in Ukrainian].

Стаття надійшла до редакції 06.10.2020

\section{G5808nc2

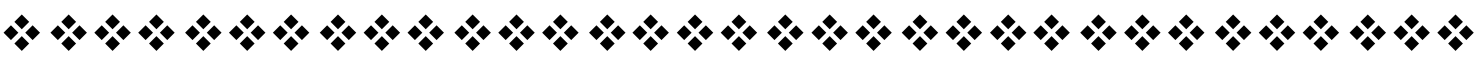

